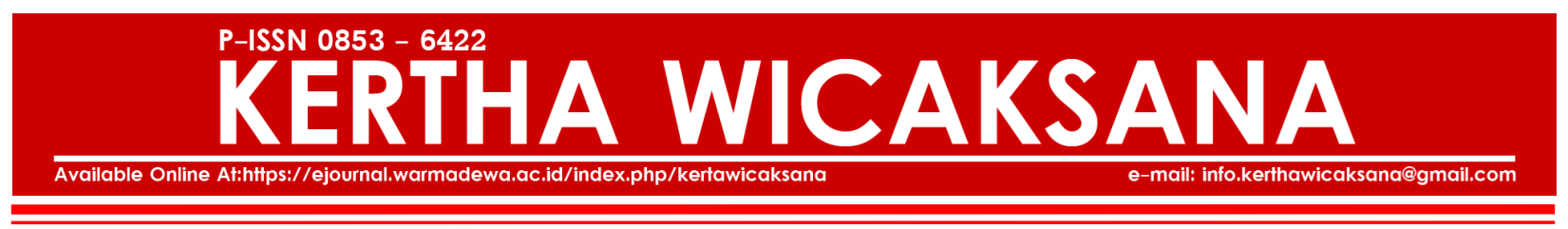

\title{
FUNGSI NASKAH AKADEMIK (NA) DALAM PEMBENTUKAN RANCANGAN PERATURAN DAERAH
}

\author{
Ni Made Jaya Senastri*, Luh Putu Suryani \\ Fakultas Hukum Universitas Warmadewa, Denpasar, Bali \\ E-mail:
}

DOI: $10.22225 / \mathrm{kw} \cdot 12 \cdot 1.419 .38-45$

Halaman: 38 - 45

\begin{abstract}
Abstrak
Penelitian ini berjudul fungsi naskah akademik dalam pembentukan rancangan peraturan daerah. Permasalahan yang dapat dibahas dalam penelitian ini adalah, bagaimanakah fungsi Naskah Akademik (NA) dalam pembentukan Rancangan Peraturan Daerah. Penyusunan Naskah Akademik ini sangat penting, jika ditinjau dari aspek daya guna suatu Rancangan Peraturan Daerah yang memang dibutuhkan oleh masyarakat dan pemerintah daerah, hal ini disebabkan karena penyusunan Naskah Akademik merupakan naskah hasil penelitian atau pengkajian hukum dan hasil penelitian lainnya terhadap suatu masalah tertentu yang dapat dipertangungjawabkan secara ilmiah mengenai pengaturan masalah tersebut dalam suatu Rancangan Undang-Undang, Rancangan Peraturan Daerah Provinsi, Rancangan Peraturan Daerah Kabupaten/Kota, sebagai solusi terhadap permasalah dan kebutuhan hukum masyarakat.

Pemerintah daerah melalui pelaksanaan otonomi mempunyai peran yang sangat penting dalam pencapain tujuan Negara, khususnya dalam hal pencapaian kesejahteraan dan keadilan dalam masyarakat.

Dalam pembentukan Perda seringkali ada asumsi yang keliru bahwa Perda hanya semata-mata dalam upaya peningkatkan Pendapatan Asli Daerah (PAD), sejatinya pembentukan PERDA tidak hanya dalam rangka peningkatan PAD melalui Perda Pajak Daerah dan Retribusi Daerah, tetapi pembentukan Perda untuk segala aspek pembangunan yang sesuai dengan spirit otonomi seluas-luasnya. Kementerian Dalam Negeri pada tanggal 13 Juni 2016 mempublikasikan bahwa terdapat 1765 Perda dicabut atau direvisi, tujuan pencabutan atau revisi ini untuk memperkuat daya saing bangsa, karena ribuan Perda ini dianggap menghambat pertumbuhan ekonomi daerah, memperpanjang birokrasi, hambat investasi, dan kemudahan berusaha, dan bertentangan dengan semangat kebhinekaan dan persatuan.
\end{abstract}

Kata Kunci: Naskah Akademik, Peraturan daerah, Hukum

\begin{abstract}
This study entitled the function of academic manuscripts in the formulation of draft local regulations. The problem that can be discussed in this research is, how is the function of Academic Paper (NA) in formulating the Draft of Local Regulation. Preparation of Academic Paper is very important, if viewed from the aspect of the usefulness of a draft Local Regulations that are needed by the community and local government, this is because the preparation of Academic Paper is a script of research results or legal studies and other research results on a particular problem that can scientifically responsible for the regulation of the matter in a Draft Law, the Draft of Provincial Regulation, the Draft of Regency / City Regulation, as a solution to the problems and legal needs of the community. Local government through the implementation of autonomy has a very important role in the achievement of the purpose of the State, especially in terms of achieving welfare and justice in society.

In the formation of local regulations, there is often a false assumption that the local regulation is merely in the effort to increase the original regional revenue (PAD), in fact the formation of local regulations not only in the framework of increasing local revenue through regional taxes and regional levies, but the establishment of local regulations for all aspects of development with the spirit of autonomy as widely as possible. The Ministry of Home Affairs on June 13, 2016 published that 1765 local regulations were revoked or revised to strengthen the nation's competitiveness, as thousands of these laws are perceived as impeding regional economic growth, extending bu-
\end{abstract}


Keywords: Academic Paper, Local Regulation, Law

\section{PENDAHULUAN}

Hukum ada pada setiap masyarakat dimanapun mereka berada, oleh karena itu keberadaan atau eksistensi hukum sifatnya universal. Hukum tidak dapat dipisahkan dengan masyarakat tetapi justru mempunyai hubungan yang timbal balik. Norma hukum dibuat menurut beberapa cara yaitu norma umum melalui kebiasaan atau undan-undang, norma khusus melalui tindakan-tindakan pengadilan dan administrasi atau transaksi hukum ${ }^{1}$.

Hukum selalu dibuat oleh suatu tindakan yang dengan sengaja bertujuan untuk menciptakan hukum, kecuali kalau hukum itu berasal dari kebiasaan.

Dalam kehidupan masyarakat nilai-nilai semua bidang kehidupan akan memberikan pengaruh terhadap hukum, ini berarti kehidupan masyarakat dinamis, terus-menerus mengalami perkembangan dan perubahan. Menurut Sunaryati Hartono ada 4 (empat) fungsi hukum dalam pembangunan, yaitu:

1) Hukum sebagai pemelihara ketertiban dan keamanan;

2) Hukum sebagai sarana pembangunan;

3) Hukum sebagai sarana penegak keadilan; dan

4) Hukum sebagai sarana pendidikan masyarakat.

Sedangkan menurut J.B.J.M.ten Berge menyebutkan prinsip-prinsip negara hukum adalah sebagai berikut:

1) Asas Legalitas; Pembatasan kebebasan warga negara harus ditemukan dasarnya dalam undangundang yang merupakan peraturan umum. Undang-undang secara umum harus memberikan jaminan (terhadap warga negara) dari tindakan yang sewenang-wenang, kolusi, dan berbagai jenis tindakan yang tidak benar. Pelaksanaan wewenang oleh organ pemerintahan harus ditemukan dasarnya pada undang-undang tertulis (undang-undang formal).

2) Perlindungan hak-hak asasi

3) Pemerintah terikat pada hukum

4) Monopoli paksaan pemerintah untuk menjamin penegakan hukum. Hukum harus dapat ditegakkan ketika hukum itu dilanggar. Pemerintah harus menjamin bahwa di tengah masyarakat terdapat instrumen yuridis penegakan hukum. Pemerintah dapat memaksa seseorang yang melanggar hukum melalui sistem peradilan negara. Memaksa hukum publik secara prinsip merupakan tugas pemerintah.

5) Pengawasan oleh hakim yang merdeka, superioritas hukum tidak dapat ditampilkan jika aturan-aturan hukum hanya dilaksanakan organ pemerintahan. Oleh karena itu, dalam setiap negara hukum diperlukan pengawasan oleh hakim yang merdeka ${ }^{3}$.

Salah satu tuntutan aspirasi rakyat Indonesia setelah jatuhnya Pemerintahan Orde Baru adalah reformasi di bidang hukum demi terwujudnya supremasi hukum di Indonesia. Sistem hukum yang hendak diwujudkan dalam kerangka hukum nasional di Indonesia merupakan suatu sistem hukum yang efektif dalam proses penyelenggaraan negara di Indonesia.

Negara Indonesia sebagaimana amanat dalam Undang-Undang Dasar Negara Republik Indonesia 1945 (selanjutnya disebut UUDNRI 1945) dalam Pembukaan Alinea IV menyatakan :

Kemudian dari pada itu untuk membentuk suatu Pemerintah Negara Indonesia yang melindungi segenap bangsa Indonesia dan seluruh tumpah darah Indonesia dan untuk memajukan kesejahteraan umum, mencerdaskan kehidupan bangsa, dan ikut melaksanakan ketertiban dunia yang berdasarkan kemerdekaan, perdamaian abadi dan keadilan sosial, maka disusunlah kemerdekaan kebangsaan Indonesia itu dalam suatu undang-undang dasar negara Indonesia, yang terbentuk dalam suatu susunan Negara Republik Indonesia yang berkedaulatan rakyat dengan berdasarkan kepada Ketuhanan Yang Maha Esa, Kemanusiaan Yang Adil dan Beradab, Persatuan Indonesia dan Kerakyatan yang dipimpin oleh hikmat kebijaksanaan dalam Permusyawaratan/Perwakilan, serta dengan mewujudkan suatu Keadilan sosial bagi seluruh rakyat Indonesia.

Alinia IV tersebut diatas mempunyai makna yang sangat penting dari aspek tujuan Negara Republik Indonesia

Dalam pelaksanaan tujuan Negara Republik Indonesia, jika dikaitkan dengan dengan ketentuan pasal 18 UUDNRI 1945 yang menyatakan :

Ayat (1) Negara Kesatuan Republik Indonesia dibagi atas daerah-daerah provinsi dan daerah provinsi itu dibagi atas kabupaten dan kota, yang tiap-tiap provinsi, kabupaten, kota itu mempunyai pemerintahan daerah, yang diatur dengan undang-undang.

Ayat (2) Pemerintahan daerah provinsi, daerah

1. Hans Kelsen, Teori Umum tentang Hukum dan Negara, (Nusa Media, Bandung, 2006), hal. 165

2. H. Riduan Syahrani, Rangkuman Intisari Ilmu Hukum, (Citra Aditya Bakti, Bandung, 2015), hal. 31

3. Ridwan HR, Hukum Administrasi Negara, (Grafindo Persada, Jakarta, 2006), hal. 9 
kabupaten, dan kota mengatur dan mengurus sendiri urusan pemerintahan menurut asas otonomi dan tugas pembantuan.

Ayat (5) Pemerintah daerah menjalankan otonomi seluas-luasnya,kecuali urusan pemerintahan yang oleh undang-undang ditentukan sebagai urusan Pemerintah Pusat.

Ayat (6) Pemerintahan daerah berhak menetapkan peraturan daerah dan peraturan peraturan lain untuk melaksanakan otonomi dan tugas pembantuan.

Sebagai pengejawantahan amanat dari otonomi daerah, maka salah satu amanat penting tersebut adalah kewajiban Pemerintahan Daerah dalam pembentukan suatu peraturan daerah untuk penyelenggaraan pembangunan di segala bidang yang menjadi kewajiban pemerintahan daerah. Perda sebagai produk peraturan perundang-undangan di daerah pada hakekatnya merupakan konsekuensi dari diberlakukannya prinsip desentralisasi. Sebagai suatu produk hukum, PERDA merupakan bagian yang tidak dapat dipisahkan dari satu kesatuan sistem hukum nasional. Konsep desentralisasi menurut Hans Kelsen berkaitan dengan pengertian Negara dalam arti tatanan norma hukum (legal norm order ${ }^{4}$ )

Dalam Undang-undang Nomor 12 Tahun 2011 dalam pasal 14 menyatakan :

Materi muatan Peraturan Daerah Provinsi dan Peraturan Daerah Kabupaten/Kota berisi muatan dalam rangka penyelenggaraan otonomi daerah dan tugas pembantuan serta menampung kondisi khusus daerah dan/atau penjabaran lebih lanjut Peraturan Perundangundangan yang lebih lanjut.

Dalam penyusunan Rancangan Peraturan Daerah, satu bagian proses yang penting diawal menyusunan RANPERDA adalah proses penyusunan Naskah Akademik, sebagaimana pasal 57 menyatakan :

1) Penyusunan Naskah Akademik Rancangan Peraturan Daerah Provinsi dilakukan sesuai dengan teknik penyusunan Naskah Akademik

2) Ketentuan mengenai teknik penyusunan Naskah Akademik sebagaimana dimaksud pada ayat (1) tercantum dalam Lampiran I yang merupakan bagian tidak terpisahkan dari Undang-Undang ini.

Penyusunan Naskah Akademik ini sangat penting, jika ditinjau dari aspek daya guna suatu Rancangan Peraturan Daerah yang memang dibutuhkan oleh masyarakat dan pemerintah daerah, hal ini disebabkan karena penyusunan naskah akademik merupakan naskah hasil penelitian atau pengkajian hukum dan hasil penelitian lainnya terhadap suatu masalah tertentu yang dapat dipertangungjawabkan secara ilmiah mengenai pengaturan masalah tersebut dalam suatu Rancangan Undang-Undang, Rancangan Peraturan
Daerah Provinsi, Rancangan Peraturan Daerah Kabupaten/Kota, sebagai solusi terhadap permasalah dan kebutuhan hukum masyarakat.

Pemerintah daerah melalui pelaksanaan otonomi mempunyai peran yang sangat penting dalam pencapain tujuan Negara, khususnya dalam hal pencapaian kesejahteraan dan keadilan dalam masyarakat.

Dalam pembentukan Perda seringkali ada asumsi yang keliru bahwa PERDA hanya semata-mata dalam upaya peningkatkan Pendapatan Asli Daerah (PAD), sejatinya pembentukan PERDA tidak hanya dalam rangka peningkatan PAD melalui PERDA Pajak Daerah dan Retribusi Daerah, tetapi pembentukan PERDA untuk segala aspek pembangunan yang sesuai dengan spirit otonomi seluas-luasnya. Kementerian Dalam Negeri pada tanggal 13 Juni 2016 mempublikasikan bahwa terdapat 1765 PERDA dicabut atau direvisi, tujuan pencabutan atau revisi ini untuk memperkuat daya saing bangsa, karena ribuan PERDA ini dianggap menghambat pertumbuhan ekonomi daerah, memperpanjang birokrasi, hambat investasi, dan kemudahan berusaha, dan bertentangan dengan semangat kebhinekaan dan persatuan.

Dari hal tersebut diatas, maka problematika pembentukan PERDA dapat ditinjau baik secara procedural pembentukan dan secara substansial, untuk mewujudkan adanya PERDA yang betul-betul memberikan kemanfaatan, keadilan dan kepastian hukum bagi masyarakat.

Berdasarkan latar belakang tersebut diatas maka dalam permasalahan yang dapat dikemukakan adalah : Bagaimanakah fungsi Naskah Akademik (NA) dalam pembentukan Rancangan Peraturan Daerah?

\section{PEMBAHASAN}

\section{A. Fungsi Naskah Akademik Dalam Pembentukan Rancangan Peraturan Daerah}

Jimly Asshiddiqie menyatakan bahwa dalam mewujudkan sistem hukum yang efektif tersebut, diperlukan penataan kembali kelembagaan hukum yang didukung oleh kualitas sumber daya manusia, kultur dan kesadaran hukum masyarakat yang terus meningkat, dan diiringi dengan pembaruan materi hukum yang terstruktur sesuai dengan perkembangan kebutuhan masyarakat Indonesia.

Hukum memiliki peranan yang sangat vital karena merupakan alat pengatur yang sah dalam negara hukum. Oleh karena itu, hukum memiliki sifat memaksa demi terwujudnya jaminan ketertiban, keadilan dan kepastian dalam masyarakat Dengan demikian, hukum menjadi pengatur dan penggerak masyarakat, atau dikenal istilah law is tool of social engineering

Dalam arti yang luas, analisis perumusan perundangan adalah suatu bentuk riset terapan yang dil-

4. B. Hestu Cipto Handoyo, Prinsip-Prinsip Legal Drafting dan Desain Naskah Akademik, (Universitas Atma Jaya, Yogyakarta, 2008), hal 120 
akukan untuk memperoleh pengertian tentang masalah -masalah legal dan sosio teknis yang lebih dalam dan untuk menghasilkan pemecahan-pemecahan yang lebih baik. Konsep analisis perumusan perundangan diterapkan baik terhadap proses (kegiatan) maupun hasil kegiatannya. Untuk itu, analisis perumusan perundangan berupaya memperbaiki proses pengambilan keputusan dalam situasi yang khusus melalui upaya legislasi maupun pendidikan.

Istilah perundangan dalam banyak hal mengacu pada istilah "kebijakan" (Policy) dipergunakan untuk menunjuk perilaku seorang aktor (misalnya pejabat, suatu kelompok atau suatu lembaga pemerintah) atau sejumlah aktor dalam suatu bidang kegiatan tertentu. Dalam arti yang hampir sama, dapat dinyatakan perundangan sebagai "serangkaian kegiatan yang sedikit banyak berhubungan beserta konsekuensikonsekuensinya bagi mereka yang bersangkutan daripada suatu keputusan tersendiri". Dari berbagai definisi tersebut, pandangan terhadap perundangan dapat dibagi menjadi dua wilayah kategori : Pertama, pendapat para ahli yang menyamakan perundangan dengan tindakan pemerintah. Dalam pandangan ini menganggap semua tindakan pemerintah dapat disebut sebagai perundangan. Sedangkan kategori kedua, perundangan dimaknai sebagai proses perumusan kebijakan, pelaksanaan kebijakan dan penilaian kebijakan atau serangkaian intruksi dari para pembuat kebijakan kepada pelaksana kebijakan yang menjelaskan tujuan dan cara untuk mencapai tujuan.

Dalam kategori kedua ini, perundangan dipengaruhi oleh aktor dan faktor bukan pemerintah seperti misalnya, kelompok kepentingan, kelompok penekan dan aktor individual yang berpengaruh (elit strategis). Keterlibatan aktor-aktor dalam perumusan perundangan menjadi ciri khusus dari perundangan.

Dalam hal ini dalam proses pembentukannya dapat saja merupakan hasil dari tarik ulur (bargaining) antar pihak yang terlibat di dalamnya, baik secara langsung maupun tidak langsung.

1) Secara prinsip dalam pembentukan peraturan perundang-undangan harus berdasarkan prinsip ${ }^{5}$ : Keberlakukan filosofis, dalam prinsip ini memiliki makna bahwa pembentukan peraturan perundangundangan tidak boleh bertentangan dengan Rechtidee masyarakat yakni apa yang masyarakat harapkan dari hukum yang terdiri dari keadilan, kemanfaatan, dan ketertiban maupun kesejahteraan. Cita hukum atau rechtsidee tumbuh dalam sistem nilai masyarakat tentang baik dan buruk, pandangan mereka mengenai hubungan individual dan kemasyarakatan. Cita hukum inilah bersifat filosofis artinya menyangkut pandangan mengenai inti atau hakikat tentang sesuatu.
2) Keberlakukan yuridis, dalam prinsip ini memiliki makna suatu peraturan merupakan bagian dari suatu kaidah hukum tertentu yang didalamnya kaidah-kaidah hukum saling merujuk yang satu terhadap yang lain, sistem hukum yang demikian merupakan keseluhuran hirarki Sifat perundangan sebagai arah tindakan dapat dipahami secara lebih baik jika sifat ini dirinci dalam beberapa kategori konsep seperti; tuntutan-tuntutan kebijakan (policy demands), keputusan-keputusan kebijakan (policy decision), pernyataan-pernyataan kebijakan (policy statements), hasil-hasil kebijakan (policy outputs) dan dampak-dampak kebijakan (Outcomes).

Pembentukan Undang-Undang, termasuk pembentukan Peraturan Daerah berdasarkan pasal 43 ayat (3) dan pasal 57 ayat (1) Undang-Undang Nomor 11 Tahun 2012, harus disertai dengan naskah akademik. Menurut Harry Alexander yang dimaksud dengan naskah akademik adalah merupakan naskah awal yang memuat gagasan-gagasan pengaturan dan materi muatan perundang-undangan bidang tertentu ${ }^{6}$. Bentuk dan isi naskah akademik memuat gagasan pengaturan suatu materi hukum bidang tertentu yang telah ditinjau secara holistic futuristic dan dari berbagai aspek ilmu, dilengkapi dengan referensi yang memuat urgensi, konsepsi, landasan, dasar hukum, prinsip-prinsip yang digunakan serta pemikiran tentang norma-norma yang telang dituangkan ke dalam bentuk pasal-pasal yang dapat dipertanggungjawabkan secara ilmu hukum dan politik hukum yang digariskan ${ }^{7}$.

Pembuatan naskah akademik merupakan suatu upaya pendekatan secara menyeluruh dari sebuah rencana pembentukan Rancangan Peraturan Daerah. Pendekatan yang dijalankan melalui sebuah metode riset sebagai langkah awal untuk mengetahui realita kepentingan berbagai pihak baik masyarakat maupun pemerintah.

Dalam pembentukan suatu Peraturan Daerah terdapat beberapa faktor yang melandasi yaitu : Pertama, bergaining (tawar menawar). Bentuk pembuatan keputusan yang paling umum dalam sistem politik adalah tawar-menawar (bargaining). Tawar menawar dapat didefinisikan sebagai proses dimana dua orang atau lebih yang mempunyai kekuasaan atau wewenang untuk mengatur paling sedikit sebagian dari tujuan yang tidak mereka sepakati agar dapat dirumuskan rangkaian kegiatan yang dapat diterima bersama tetapi tidak perlu ideal bagi pengikutnya. Secara singkat, dalam tawar menawar terdapat negosiasi, saling memberi dan menerima, dan kesepakatan untuk mencapai posisi yang dapat diterima satu sama lain.

Kedua, persuasi. Persuasi diartikan sebagai suatu usaha untuk meyakinkan orang lain mengenai kebenaran atau nilai yang dimiliki oleh seseorang, sehingga

5. Sirajuddin, Fatkhurohman, Zulkarnain, Legislative Drafting Pelembagaan Metode Partisipatif dalam Pembentukan Peraturan Perundangundangan, (In-Trans Publishing Malang, 2007), hal. 14

6. Ibid, hal. 171

7. Harry Alexander, 2004, Panduan Perancangan Undang-Undang di Indonesia, Jakarta, XSYS Solusindo, hal. 120 
mereka mau menerimanya sebagai miliknya sendiri. Persuasi tidak seperti menawar, orang membujuk dalam tawar-menawar berusaha untuk mendapatkan dukungan bagi apa yang diinginkannya dengan kadang -kadang merubah pendapatnya sendiri. Sedangkan orang yang melakukan persuasi adalah yang berusaha mendekati orang lain untuk mengerjakan dengan cara tertentu.

Sebagai sebuah hasil pengkajian yang digunakan sebagai bahan awal penyusunan RANPERDA maka naskah akademik merupakan naskah yang didalamnya termuat pokok-pokok pikiran atau gagasan awal yang akan dituangkan dalam sebuah naskah rancangan peraturan daerah. Jika pengkajian tidak dilakukan secara mendalam maka menurut Hikmahanto Juwana, suatu peraturan perundang-undangan memiliki potensi tidak dapat dilaksanakan, misalnya ${ }^{8}$ :

1) Ini terjadi terhadap pembuatan peraturan perundang-undangan yang merupakan pesanan elit politik, negara asing, maupun lembaga keuangan internasional. Disini peraturan perundang-undangan dianggap sebagai komoditas, bukan karena kebutuhan masyarakat, melainkan agar Indonesia memiliki peraturan yang sebanding dengan negara industri. Sementara itu negara asing atau lembaga keuangan internasional dapat menjadikan syarat peraturan perundang-undangan tertentu untuk memberikan pinjaman atau hibah luar negeri.

2) Peraturan perundang-undangan yang menjadi komoditas, biasanya kurang memperhatikan isu penegakan hukum. Sepanjang dari pembuatan peraturan perundang-undangan telah didapat maka penegakan hukum bukanlah hal penting. Bahkan peraturan perundang-undangan seperti ini tidak realistis untuk ditegakkan karena dibuat dengan cara mengadopsi langsung peraturan perundang-undangan negara lain yang notabene infrastruktur hukum yang jauh berbeda dari Indonesia. Secara sistematis, ada baiknya tahapan penyusunan naskah akademik dilakukan melalui tahapan berikut:

1) Tahap persiapan penyusunan;

2) Tahap diskusi public;

3) Tahap penyusunan Naskah Akademik;

4) Tahap uji sahih Naskah Akademik;

5) Tahap Evaluasi Naskah Akademi;

6) Tahap Penyempurnaan Naskah Akademik; dan

7) Tahap Penyelarasan.

Dalam Lampiran Undang-Undang Nomor 12 Tahun 2011, di jelaskan bahwa Sistematika Naskah Akademik adalah sebagai berikut:

1) .Judul;
2) Kata Pengantar;

3) Daftar Isi;

4) Bab I, Pendahuluan;

5) Bab II, Kajian Teoritis dan Praktik Emperis;

6) Bab III, Evaluasi dan Analisis Peraturan Perundang -Undangan Terkait;

7) Bab IV, Landasan Filosofis, Sosiologis, dan Yuridis;

8) Bab V, Jangkauan, Arah Pengaturan, dan Ruang Lingkup Materi Muatan Undang-Undang, Peraturan Daerah Provinsi, atau Peraturan Daerah Kabupaten/Kota;

9) Bab VI, Penutup;

10) Daftar Pustaka

11) Lampiran: Rancangan Peraturan Perundangundangan

Sistematika ini merupakan satu kesatuan yang utuh, sehingga terdapat hubungan antara kajian akademik dan substansial yang tidak terpisahkan antara naskah akademik dengan Rancangan Peraturan Perundang-undangan. Dalam suatu pembentukan Rancangan Peraturan Daerah, hal yang sangat harus diperhatikan adalah berkaitan dengan dasar hukum pembentukan RANPERDA, apakah karena perintah peraturan perundang-undangan yang lebih lebih tinggi atau tidak. Hal ini akan menentukan identifikasi masalah dalam naskah akademik. Pada dasarnya identifikasi masalah dalam suatu Naskah Akademik mencakup empat pokok masalah, yaitu:

1) Permasalahan apa yang dihadapi dalam kehidupan berbangsa, bernegara dan bermasyarakat serta bagaimana permasalahan tersebut dapat diatasi.

2) Mengapa perlu Rancangan Undang-Undang atau Rancangan Peraturan Daerah sebagai dasar pemecahan masalah tersebut, yang membenarkan pelibatan Negara dalam penyelesaian masalah tersebut.

3) Apa yang menjadi pertimbangan atau landasan filosofis, sosiologis, yuridis pembentukan Rancangan Undang-Undang atau Rancangan Peraturan Daerah.

4) Apa sasaran yang akan diwujudkan, ruang lingkup pengaturan, jangkauan dan arah pengaturan.

Dengan adanya identifikasi masalah yang tepat, maka kegunaan penyusunan Naskah Akademik sebagai acuan atau referensi penyusunan dan pembahasan Rancangan Undang-Undang dan Peraturan Daerah akan tercapai.

Dalam Penyusunan Naskah Akademik pada dasarnya merupakan suatu kegiatan penelitian, sehingga digunakan metode penyusunan Naskah Akademik yang berbasiskan metode penelitian hukum atau

8. Pendapat Hikmahanto Juwana yang dikutif dalam Desertasi Yuliandri, 2007, Asas-Asas Pembentukan Peraturan Perundang-Undangan Yang Baik Dalam Rangka Pembuatan Undang-Undang Yang Berkelanjutan, Program Pascasarjana Universitas Airlangga, Surabaya, hal. 172 
penelitian lain. Penelitian hukum dapat dilakukan melalui metode yuridis normative dan metode yuridis emperis. Metode yuridis emperis dikenal juga dengan penelitian sosiolegal. Metode yuridis normative dilakukan melalui studi pustaka yang menelaah berupa Peraturan Perundang-undangan, putusan pengadilan, perjanjian, kontrak, atau dokumen hukum lainnya, serta hasil penelitian, hasil pengkajian, dan referensi lainnya. Metode yuridis normatif dapat dilengkapi dengan wawancara, diskusi (focus group discussion), dan rapat dengar pendapat. Metode yuridis emperis atau sosiolegal adalah penelitian yang diawali dengan penelitian normative atau penelaahan terhadap peraturan perundang-undangan yang dilanjutkan dengan observasi yang mendalam serta penyebarluasan kuisioner untuk mrndapatkan data factor nonhukum yang terkait dan yang berpengaruh terhadap Peraturan Perundang-undangan yang diteliti.

\section{B. Landasan Pembentukan Peraturan Daerah Landasan Filofosis.}

Filosofis berasal dari kata filsafat yakni ilmu tentang kebijaksanaan. Berdasarkan kata tersebut maka arti filosofis tidak lain adalah sifat-sifat yang mengarah pada kebijaksanaan. Karena mengarah pada kebijaksanaan maka filosofis tidak lain adalah pandangan hidup suatu bangsa yakni nilai-nilai moral atau etika yang berisi nialai-nilai yang baik dan tidak baik. Landasan atau dasar firosofis peraturan perundang-undangan adalah landasan atau dasar yang berkaitan dengan filosofis atau ideologi negara. Setiap masyarakat mengharapkan agar hukum itu dapat menciptakan keadilan, ketertiban dan kesejahteraan. Hukum diharapkan mencerminkan nilai-nilai yang tumbuh dan dirasa adil dalam masyarakat.

Menurut Rudolp Stammler, cita hukum adalah konstruksi pikiran yang merupakan keharusan untuk mengarahkan hukum pada cita-cita yang diinginkan masyarakat. Meski merupakan titik akhir yang tidak mungkin tercapai, namun cita hukum memberikan manfaat karena mengandung dua sisi yaitu dengan cita hukum kita dapat menguji hukum positif yang berlaku dan cita hukum kita dapat mengarahkan hukum positif sebagai usaha dengan sanksi pemaksa menuju sesuatu yang adil (zwangversuch zum Richtigen"). Selanjutnya Gustav Radbruch menyatakan bahwa cita hukum berfungsi sebagai tolak ukur yang bersifat regulatif dan konstruktif. Tanpa cita hukum, hukum kehilangan maknanya.

Kendatipun demikian penilaian dan ukuran mengenai hal-hal yang bersifat baik, buruk, susila dan asusila serta adil dan tidak adil juga didasarkan pada universalitas pandangan dunia mengenai hal itu. Dengan demikian prinsip-prinsip moral universal seperti demikrasi dan hak asasi manusia juga ikut mempengaruhi pembentukan dan pemberlakuan Peraturan perundang-undangan yang baik serta sekaligus merupakan hukum yang dapat diterima berdasarkan pandangan filisofis tersebut. Dalam pembentukan peraturan perundang-undangan proses terwujudnya nilai-nilai yang terkandung dalam cita hukum kedalam norma hukum tergantung kepada tingkat kesadaran dan penghayatan akan nilai-nilai tersebut oleh para pembentuk peraturan perundangundangan. Tiadanya kesadaran akan nilai-nilai tersebut dapat terjadi kesenjangan antara cita hukum dan norma hukum yang dibuat.

Oleh karena itu dalam Negara Indonesia yang memiliki cita hukum Pancasila sekaligus sebagai norma fundamental negara, maka peraturan perundangundangan yang hendak dibuat, hendaknya diwarnai dan dialiri nilai-nilai yang terkandung dalam cita hukum tersebut. Menurut Lampiran I Undang-Undang Nomor 12 tahun 2011 tentang Pembentukan Peraturan Perundang-undangan bahwa landasan filosofis merupakan pertimbangan atau alasan yang menggambarkan bahwa peraturan yang dibentuk mempertimbangkan pandangan hidup, kesadaran dan cita hukum yang meliputi suasana kebatinan serta falsafah bangsa Indonesia yang bersumber dari Pancasila dan Pembukaan Undang-undang Dasar Negara Republik Indonesia Tahun 1945.

Nilai-nilai Pancasila ini dijabarkan dalam hukum yang dapat menunjukkan nilai-nilai kehidupan dengan berdasarkan Ketuhanan yang Maha Esa dengan berdasarkan ajaran agama, nilai keadilan, ketertiban dan kesejahteraan. Rumusan Pancasila ini yang merupakan dasar hidup Negara Indonesia dituangkan dalam pembukaan UUD Republik Indonesia Tahun 1945. Yang dinyatakan dengan tegas bahwa Indonesia adalah Negara hukum .

\section{Landasan Yuridis}

Teori umum tentang hukum yang dikembangkan oleh Kelsen meliputi dua aspek penting, yaitu aspek statis yang melihat perbuatan yang diatur oleh hukum, dan aspek dinamis yang melihat hukum yang mengatur perbuatan tertentu. Friedman mengungkapkan dasardasar esensial dari pemikiran Kelsen sebagai berikut ${ }^{10}$ :

1) Tujuan teori hukum, seperti tiap ilmu pengetahuan adalah untuk mengurangi kekacauan dan kemajemukan menjadi satu.

2) Teori hukum adalah ilmu pengetahuan mengenai hukum yang berlaku, bukan mengenai hukum yang seharusnya.

3) Hukum adalah ilmu pengetahuan normative, bukan ilmu alam.

4) Teori hukum sebagai teori tentang norma-norma, tidak ada hubungannya dengan daya kerja norma-

9. Maria Farida Indrati S., Ilmu Perundang-undangan (2), Proses dan Teknik Penyusunan, (Kanisius, 2007), hal 237

10. W. Friedmann, penerjemah Mohamad Arifin, Teori dan Filsafat Hukum, (Raja Grafindo Persada, Jakarta, 1994) 
norma hukum.

5) Teori hukum adalah formal, suatu teori tentang cara menata, mengubah, isi dengan cara khusus. Hubungan antara teori hukum dan sistem yang khas dari hukum positif ialah hubungan apa yang mungkin dengan hukum yang nyata.

Peraturan perundang-undangan merupakan salah satu unsur produk hukum, maka prinsip-prinsip pembentukan, pemberlakuan dan penegakannya harus mengandung nilai-nilai hukum pada umumnya. Berbeda dengan nilai-nilai sosial lainnya, sifat kodratinya dari nilai hukum adalah mengikat secara umum dan ada pertanggungjawaban konkret yang berupa sanksi duniawi ketika nilai hukum tersebut dilanggar.

Negara Indonesia adalah Negara yang berdasarkan atas hukum (Rechstaat) bukan berdasarkan atas kekuasaan (Machtstaat). Oleh karena itu setiap produk peraturan-peraturan perundang-undangan yang dibuat harus memenuhi tata cara yang ditetapkan oleh undang -undang dengan memenuhi asas-asas yang terdapat dalam nafas negara hukum.

Landasan yuridis merupakan pertimbangan atau alasan yang menggambarkan bahwa peraturan yang dibentuk untuk mengatasi permasalahan hukum atau mengisi kekosongan hukum dengan mempertimbangkan aturan yang telah ada, yang akan diubah atau yang akan dicabut guna menjamin kepastian hukum dan rasa keadilan masyarakat.

Dengan demikian apabila diterapkan maka landasan yuridis adalah landasan hukum (yuridische gelding) yang menjadi dasar kewenangan (bevoegdheid atau competentie) pembuatan peraturan perundangundangan.

Dasar hukum kewenangan membentuk peraturan perundang-undangan sangat diperlukan. Misalnya, Pasal 20 ayat (1) Undang-Undang Dasar Negara Republik Indonesia Tahun 1945 memberikan kewenangan kepada Dewan Perwakilan Rakyat untuk membentuk undang-undang. Demikian pula ketentuan Pasal 5 ayat (2) memberikan dasar hukum kewenangan kepada Presiden dalam menetapkan Peraturan Pemerintah untuk menjalankan Undang-undang.

Dengan demikian jenis peraturan perundangundangan serta lembaga atau badan yang berwenang membentuknya harus mempunyai landasan formal secara tegas dalam peraturan perundang-undangan. Tanpa landasan formal demikian, maka prinsip negara berdasar atas hukum akan menjadi goyah. Oleh karena itu dasar yuridis sangat penting dalam pemuatan peraturan perundang-undangan yang ditandai dengan:

1) Adanya kewenangan untuk pembuat peraturan perundang-undangan, karena setiap peraturan perundang-undangan harus dibuat oleh lembaga/badan atau pejabat yang berwenang.

2) adanya kesesuaian bentuk atau jenis peraturan perundang-undangan dengan materi yang diatur, teru- tama kalau diperintahkan oleh peraturan perundang -undangan tingkat lebih tinggi atau sederajat.

3) mengikuti tata cara atau prosedur tertentu, apabila tidak diikuti maka peraturan perundang-undangan tersebut dimungkinkan batal demi hukum atau tidak/belum mempunyai kekuatan hukum mengikat.

4) tidak bertentangan dengan peraturan perundangundangan yang lebih tinggi tingkatannya. Suatu undang-undang tidak boleh mengandung kaidah yang bertentangan dengan UUD. Demikian pula seterusnya sampai pada peraturan perundangundangan tingkat lebih bawah.

Selain menentukan dasar kewenangan landasan hukum juga merupakan dasar keberadaan atau pengakuan dari suatu jenis peraturan perundangundangan adalah landasan yuridis material. Landasan yuridis material menunjuk kepada materi muatan tertentu yang harus dimuat dalam suatu peraturan perundang-undangan tertentu. Pembentuk peraturan menghendaki bahwa sesuatu materi tertentu hendaknya diatur dalam suatu peraturan perundang-undangan tertentu pula.

Dalam UUDNRI 1945 disebutkan adanya materimateri tertentu yang harus diatur dengan Undangundang. Isi atau substansi suatu peraturan perundangundangan harus sesuai dengan "wadahnya" atau jenis peraturan perundang-undangan. Selain itu, isi suatu peraturan perundang-undangan tidak boleh bertentangan dengan isi peraturan perundang-undangan yang derajatnya lebih tinggi.

\section{Landasan Sosiologis}

Pemberlakuan suatu peraturan perundangundangan jika ditinjau dari aspek sosiologis sangat ideal jika didasarkan pada penerimaan dari masyarakat tempat peraturan perundang-undangan itu berlaku, dan tidak didasarkan pada faktor kekuasaaan yang lebih menekankan pada aspek pemaksaan. Dalam kondisi yang demikian peraturan perundang-undangan tidak mungkin dilepaskan dari gejala sosial yang ada di masyarakat

Setiap norma hukum yang dituangkan dalam suatu peraturan haruslah mencerminkan tuntutan kebutuhan masyarakat sendiri akan norma hukum yang sesuai dengan realitas kesadaran hukum masyarakat, oleh karena itu dalam konsideran harus dirumuskan dengan baik, pertimbangan-pertimbangan yang bersifat empiris sehingga suatu gagasan normatif yang dituangkan dalam undang-undang benar-benar didasarkan atas kenyataan yang hidup dalam kesadaran masyarakat.

Peraturan perundang-undangan dikatakan mempunyai landasan atau dasar sosiologis (sociologische grondslag) apabila ketentuan-ketentuannya sesuai dengan keyakinan umum atau kesadaran hukum masyarakat. Landasan atau dasar sosiologis peraturan perundang-undangan adalah landasan atau dasar yang berkaitan dengan kondisi atau kenyataan yang hidup 
dalam masyarakat.

Selain landasan tersebut diatas, pembuatan peraturan perundangan-undangan yang baik juga harus memperhatikan asas-asas formal dan materiil sebagaimana dikemukakan oleh Van der Vlies yaitu asas -asas formal yang meliputi ${ }^{11}$ :

1) Asas tujuan yang jelas;

2) Asas organ/lembaga yang tepat;

3) Asas perlunya peraturan;

4) Asas dapat dilaksanakan;

5) Asas konsesnsus.

Sedangkan asas-asas materiil dalam pembentukan peraturan perundang-undangan meliputi:

1) Asas tentang terminology dan sistematika yang benar;

2) Asas tentang dapat dikenali;

3) Asas perlakuan yang sama dalam hukum;

4) Asas kepastian hukum;

5) Asas pelaksanaan hukum sesuai keadaan individual.

Pemahaman tentang asas-asas ini menjadi sangat penting, hal ini disebabkan karena asas merupakan perwujudan dari nilai-nilai yang ada di masyakarat yang mencerminkan alam cita masyarakat, sedangkan asas-asas akan diwijudkan dalam bentuk norma-norma yang tertuang dalam peraturan perundang-undangan.

\section{III.SIMPULAN}

Berdasarkan hasil analisis di atas, berikut kesimpulan yang dapat diambil:

Fungsi Naskah Akademik dalam pembentukan Rancangan Peraturan Daerah adalah sebagai landasan yang bersifat akademis, dan dapat dipertanggungjawabkan secara ilmu hukum dan politik hukum yang sesuai dengan kebutuhan masyarakat dan pemerintah, sehingga Rancangan PERDA ini jika sudah melalui pembahasan di badan legislatif dan kemudian menjadi PERDA sudah memiliki kepastian hukum dan berdayaguna, berhasilguna bagi kepentingan masyarakat dan pemerintah.

Naskah akademik merupakan satuan kesatuan dari suatu Rancangan Peraturan Daerah sehingga secara substansi harus ada kesesuain antara Naskah Akademik dan Rancangan PERDA yang tertuang dalam pasal-pasalnya. Secara substansi Rancangan Perda harus berdasarkan landasan filosofis, sosiologis, dan yuridis.

\section{DAFTAR PUSTAKA}

B. Hestu Cipto Handoyo, Prinsip-Prinsip Legal Drafting dan Desain Naskah Akademik, Universitas Atmajaya, 2008

Hans Kelsen, Teori Umum tentang Hukum dan Negara, Nusa Media, Bandung, 2006

H. Riduan Syahrani, Rangkuman Intisari Ilmu Hukum, Citra Aditya Bakti, Bandung, 2015

Harry Alexander, Panduan Perancangan UndangUndang di Indonesia, XSYS Solisindo, Jakarta, 2004

Jazim Hamidi, dkk, Teori dan Hukum Perancangan Perda, UB Press, 2012

Maria Farida Indrati S, Ilmu Perundang-undangan, Proses dan Teknik Penyusunan, Kanisius, 2007

Ridwan HR, Hukum Administrasi Negara, Grafindo Persada, Jakarta, 2006

Sirajuddin, Fatkhurohman, Zulkarnain, Legislative Drafting, Pelembagaan Metode Parsitipatif dalam Pembentukan Peraturan Perundangundangan, In-Trans Publishing Malang, 2007

W. Friedmann, penerjemah Mohamad Arifin, Teori dan Filsafat Hukum, Raja Grafindo Persada, Jakarta, 1994

Yuliandri, Asas-Asas Pembentukan Peraturan Perundang-undangan Yang Baik Dalam Rangka Pembuatan Undang-Undang yang Berkelanjutan, Program Pascasarjana Universitas Airlangga, 2007. 